\title{
Landfill Site Selection in Al-Najaf Governorate, Iraq
}

\author{
Mohammad A. Al-Anbari ${ }^{1}$, Muhannad Y. Thameer ${ }^{1}$, Nadhir Al-Ansari ${ }^{2}$ and Sven Knutsson ${ }^{2}$ \\ 1. Collage of Engineering, Babylon University, Hila 51002, Iraq \\ 2. Department of Civil Environmental and Natural Resources Engineering, Lulea University of Technology, Lulea 971 87, Sweden
}

\begin{abstract}
Solid waste management aspect is one of the most important challenges facing the local administration in the Governorate of Najaf. Therefore, this study aims to provide for solid waste management problem by choosing the best locations for the establishment of sanitary landfills in the governorate. In this study, GIS (geographic information system) and MCDA (multi-criteria decision analysis) were used based on 17 environmental, economic and geological criteria converted to input digital map layers. These were urban centres, cemetery, airports, electrical power lines, oil pipes, railways, roads, slope, historical sites, main rivers, industrial areas, religion sites, wells, military area, electrical power plants, nature reserves and national borders to select most importance sites in the governorate. AHP (analytic hierarchy process) method was used in weighting the criteria used. All layers' maps were graded from 0 (not suitable) to 5 (most suitable) using spatial information scale then SAW (simple additive weighting) method was integrated in GIS used to calculate the suitability index for the studied area. The results indicated that $4.4 \%$ of the study region is suitable for landfill siting with grading values greater than 4.0. This included five sites distributed in three qadhaas of governorate.
\end{abstract}

Key words: Multi-criteria decision analysis, GIS, Iraq, Najaf, landfill.

\section{Introduction}

Waste management is a global issue and requires maximum attention. It is highly obligatory to reduce the pollution of air and water, the dreadful effects on human health and to maintain a clean environment [1].

Waste management is "the collection, transportation, processing or disposal, and managing and monitoring of waste materials. The term usually relates to materials produced by human activity, and the process is generally undertaken to reduce its effect on health, the environment or aesthetics". Waste management is a distinct practice from resource recovery, which focuses on delaying the rate of consumption of natural resources. The management of wastes treats all materials as a single class, whether solid, liquid, gaseous or radioactive substances, and tries to reduce the harmful environmental impacts of each through different methods [2].

In Iraq, after decades of turmoil and international sanctions, many of the key infrastructures within Iraq

Corresponding author: Nadhir Al-Ansari, professor, research fields: water and environmental engineering. have fallen into disrepair, leading to a terminal decline in the provision of basic and essential services. This is particularly true for waste and resource management which has seen years of underdevelopment and deterioration. This has resulted in a lack of provision of basic public services in the waste sector which have been replaced by a burgeoning black market in waste collection, disposal and recycling [3].

The selection of a site for developing a landfill is one of the most important decisions to be made by the municipality in developing and implementing its waste management plan. The selection criteria are themselves subject to prioritization according to local climatic, political and cultural circumstances [4].

Several techniques can be found for site selection of solid waste disposal such as siting techniques combine MCDA (multi-criteria decision analysis) and GIS (geographic information system) $[5,6]$. The result of these techniques is the evaluation of the suitability for the entire study region based on suitability index, which is useful in order to make an initial ranking of the most suitable areas. 
The objective of this study is to select the best sites for appropriate landfills within Al-Najaf Governorate using the approach based on integration of GIS and MCDA. In addition, the selected landfill area must accommodate generated MSW (municipal solid waste) volume for the period 2015 2035 which was calculated.

For this purpose, 17 input digital map layers - urban centers, cemetery, airports, electrical power lines, oil pipes, railways, roads, slope, historical sites, main rivers, industrial areas, religion sites, wells, military area, electrical power plants, nature reserves and national borders were prepared and multi criteria analysis was implemented with geographic information system.

\section{Study Area}

Najaf Governorate lies between coordinates of latitudes $32^{\circ} 21^{\prime} \mathrm{N}$ and $29^{\circ} 50^{\prime} \mathrm{N}$, coordinates of longitudes $44^{\circ} 44^{\prime} \mathrm{E}$ and $42^{\circ} 50^{\prime} \mathrm{E}$ with total area of $28,824 \mathrm{~km}^{2}$ (6.6\% of Iraq). Administratively, Al-Najaf Governorate includes three qadhaas (administrative units comprising the governorate, Al-Manatheria, Al-Kufa and Al-Najaf Qadhaas). The three qadhaas are shown in Fig. 1.

\section{Methodology}

The proposed model depends on GIS for data input, storage and management, manipulation and analysis and output as suitability map in last step of this aim. MCDA method was used by AHP (analytic hierarchy process) for weighting the criteria and using SAW (simple additive weighting) integrated with GIS to find suitability index for all study area so as to elect the best area which has higher suitability index.

Seventeen criteria (urban centers, cemetery, airports, electrical power lines, oil pipes, railways, roads, slope, historical sites, main rivers, industrial areas, religion sites, wells, military area, electrical power plants, nature reserves and national borders) were used to identify the best landfill site for Al-Najaf in the GIS and MCDA. The GIS was used to organize the data by separate thematic maps or sets of data, referred to as a map layer. Suitability maps generated using spatial analysis as highlighting "suitable" geographic areas execrated from weighted and combined map layers based on previous established criteria for study area. MCDA was used to measure the relative importance weight for individual evaluation criteria. MCDA is to divide the decision problems into smaller understandable

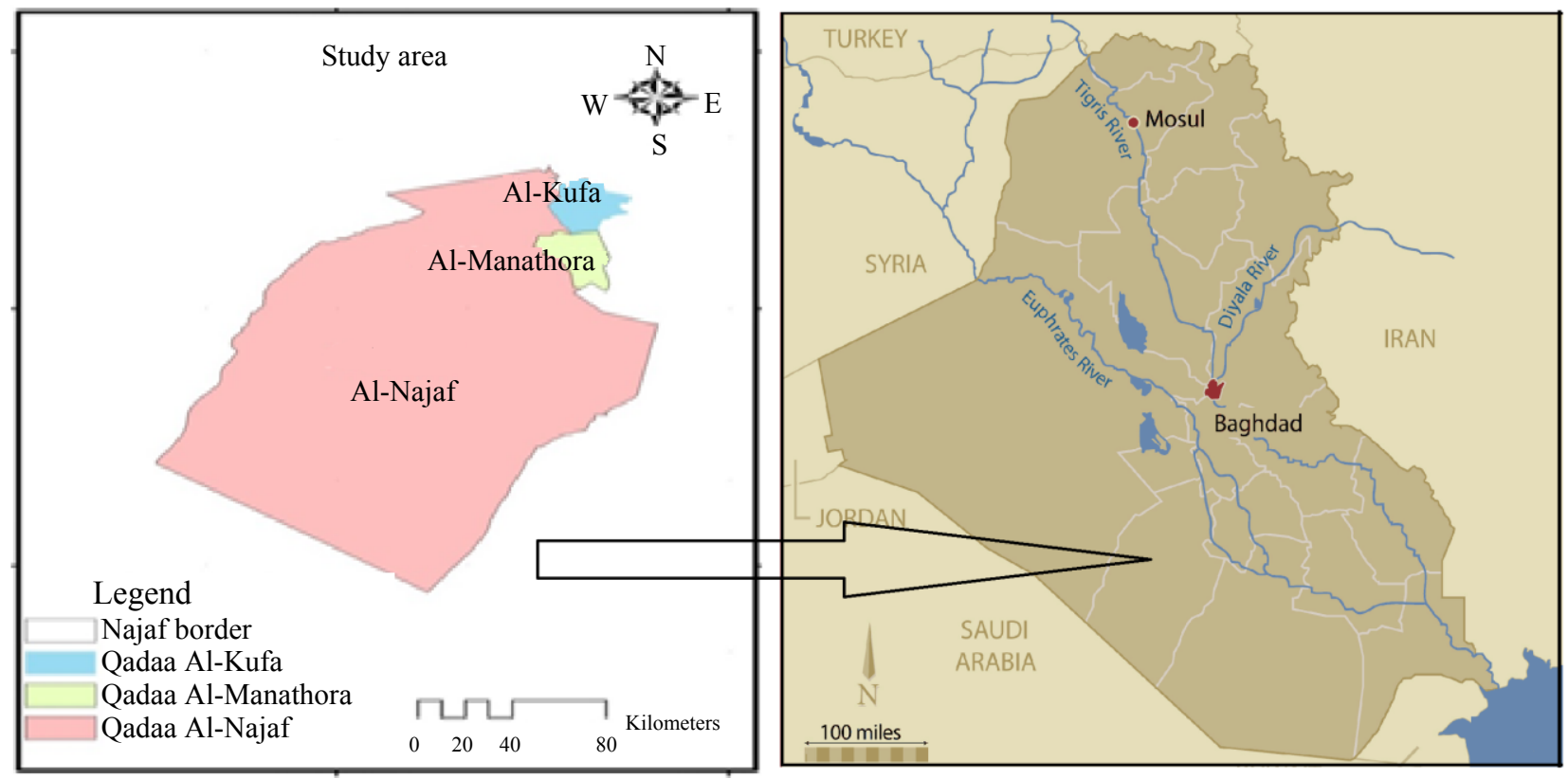

Fig. 1 Map of study area. 
parts, analyse each part separately, and then integrate the parts into a logical manner [7]. Fig. 2 shows the methodology framework.

\section{Population, Growth Rate and Solid Waste Volume for Study Area}

Based on Ref. [8], population of the study area in 2015 is about $1,389,548$ and the growth rate was $2.5 \%$.

The solid waste generation for the study area was 0.42 $\mathrm{kg} / \mathrm{capita} /$ day and about $0.23 \mathrm{~kg} / \mathrm{capita} /$ day for religious tourists according to Ref. [9] and each year about 1,485,000 religious tourists visit the city. The population and waste volume for study area during period 2015 2035 were calculated as shown in Tables 1, 2 and Fig. 3, based on this data and by using the Eq. (1) :

$$
P i=p o(1+r) n
$$

Where:

$P i=$ population in target year;

$P o=$ population in base year;

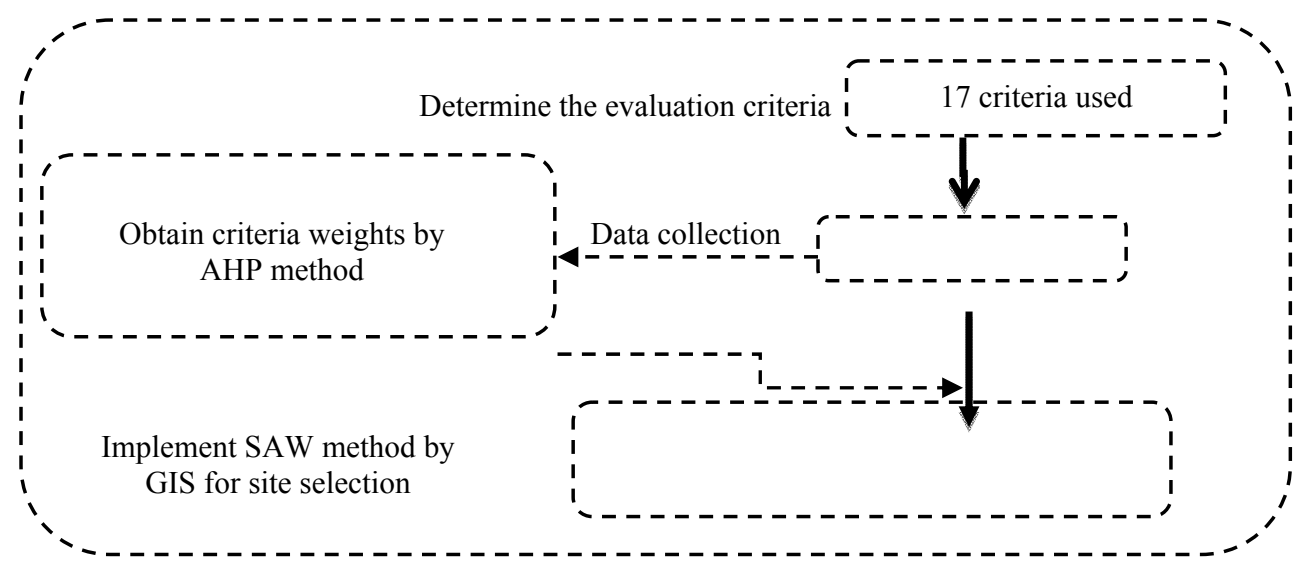

Fig. 2 Methodology framework used for landfill site selection.

Table 1 Population and waste volume.

\begin{tabular}{llll}
\hline Year & Population & Visitors & Solid waste (t) \\
\hline 2015 & $1,424,287$ & $1,485,000$ & $215,693^{*}$ \\
2016 & $1,459,894$ & $1,485,000$ & 221,078 \\
2017 & $1,496,391$ & $1,485,000$ & 226,596 \\
2018 & $1,533,801$ & $1,485,000$ & 232,252 \\
2019 & $1,572,146$ & $1,485,000$ & 238,050 \\
2020 & $1,611,450$ & $1,485,000$ & 243,993 \\
2021 & $1,651,736$ & $1,485,000$ & 250,084 \\
2022 & $1,693,029$ & $1,485,000$ & 256,328 \\
2023 & $1,735,355$ & $1,485,000$ & 262,727 \\
2024 & $1,778,739$ & $1,485,000$ & 269,287 \\
2025 & $1,823,207$ & $1,485,000$ & 276,011 \\
2026 & $1,868,788$ & $1,485,000$ & 282,902 \\
2027 & $1,915,507$ & $1,485,000$ & 289,966 \\
2028 & $1,963,395$ & $1,485,000$ & 297,207 \\
2029 & $2,012,480$ & $1,485,000$ & 304,628 \\
2030 & $2,062,792$ & $1,485,000$ & 312,236 \\
2031 & $2,114,362$ & $1,485,000$ & 320,033 \\
2032 & $2,167,221$ & $1,485,000$ & 328,025 \\
2033 & $2,221,401$ & $1,485,000$ & 336,217 \\
2034 & $2,276,936$ & $1,485,000$ & 344,614 \\
2035 & $2,333,860$ & $1,485,000$ & 353,221 \\
\hline Total & & $5,645,455$ & \\
\hline
\end{tabular}

$*=((1,424,287 \times 0.42 \times 360)+1,485,000 \times 0.23) / 1,000$. 
Table 2 Discarded and compacted waste volume in Al-Najaf.

\begin{tabular}{lll}
\hline \multirow{2}{*}{ Al-Najaf } & Accumulated waste from 2015 to $2035(\mathrm{t})^{*}$ & Volume in landfill $\left(\mathrm{m}^{3}\right)$ \\
\cline { 2 - 3 } & $5,645,455$ & $12,545,455$ \\
\hline
\end{tabular}

*Compacting density of Iraqi municipal solid waste $=0.45 \mathrm{t} / \mathrm{m}^{3}[10]$.

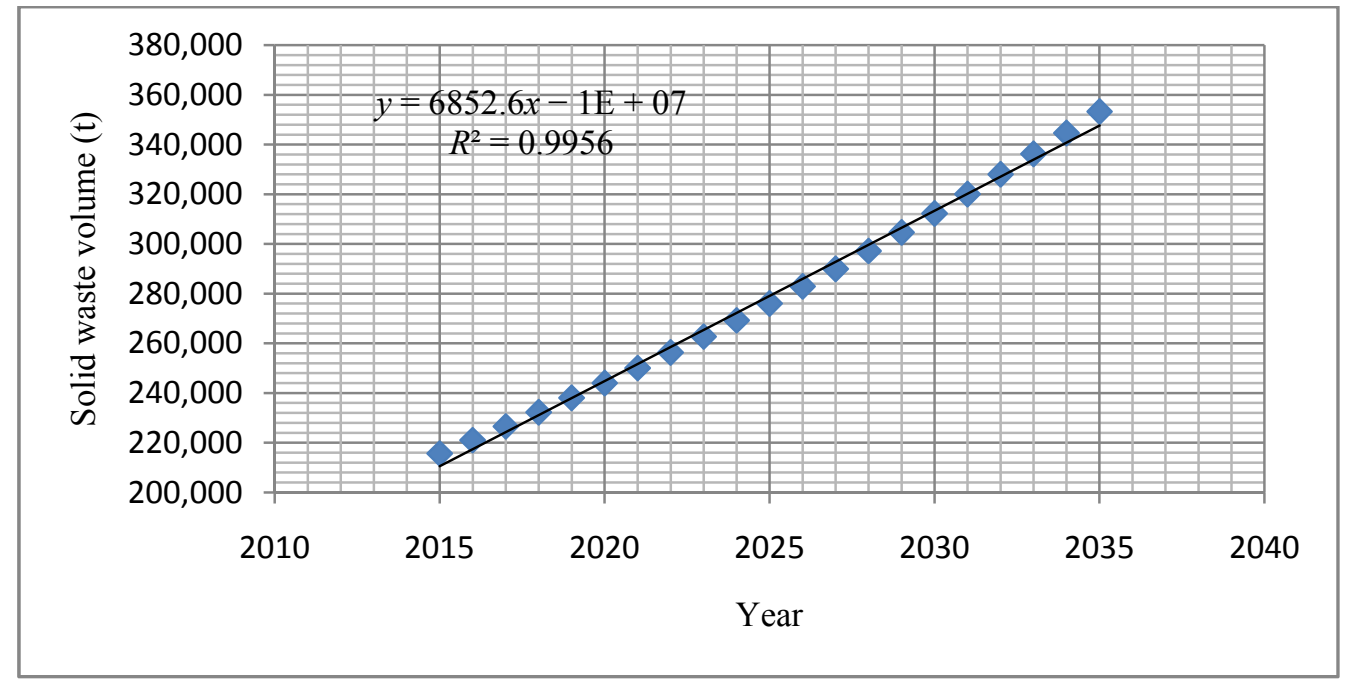

Fig. 3 Solid waste volume with year for study area.

$n=$ number of years;

$r=$ growth rate.

\section{Criteria Analysis}

For the study area, the criteria decision tree developed for the landfill site selection problem is illustrated in Fig. 4.

\section{Criteria Weights}

A weight is a measure of the relative importance of a criterion as judged by the decision maker. Assigning weights its important process for the evaluation criteria accounts for many reasons:

(1) the changes in the range of variation for each evaluation criterion;

(2) the different degrees of importance being attached to these ranges of variation [11].

There are four different techniques when assigning the weights:

- ranking;

- rating;

- pairwise comparison;

- trade of analysis method [12].
In this study, the method of pairwise comparison was used in calculating weight for the criteria. The weights of criteria have been computed using comparison matrix as shown in Fig. 5 by using scale values of $1 \sim 9$ as shown in Table 3 . The comparison matrix indicating the relative importance of the criterion in the columns compared to the criterion in the rows. For each comparison, it was decided which of the two criteria are the most important, and then a score was assigned to show how much more important it is. The resulting weights are given in Table 4.

\section{Digital Environmental Maps}

In this study, 17 input map layers were used. The selection of a new waste disposal site is a complicated process as it requires considerable expertise in diverse social and environmental fields, such as soil science, engineering, hydro-geology, topography, land use, sociology and economics [14]. This process was carried out through a multi-level screening process. Subsequently, a GIS-based constraint mapping was employed to eliminate the environmentally unsuitable sites and to narrow down the number of sites for further 


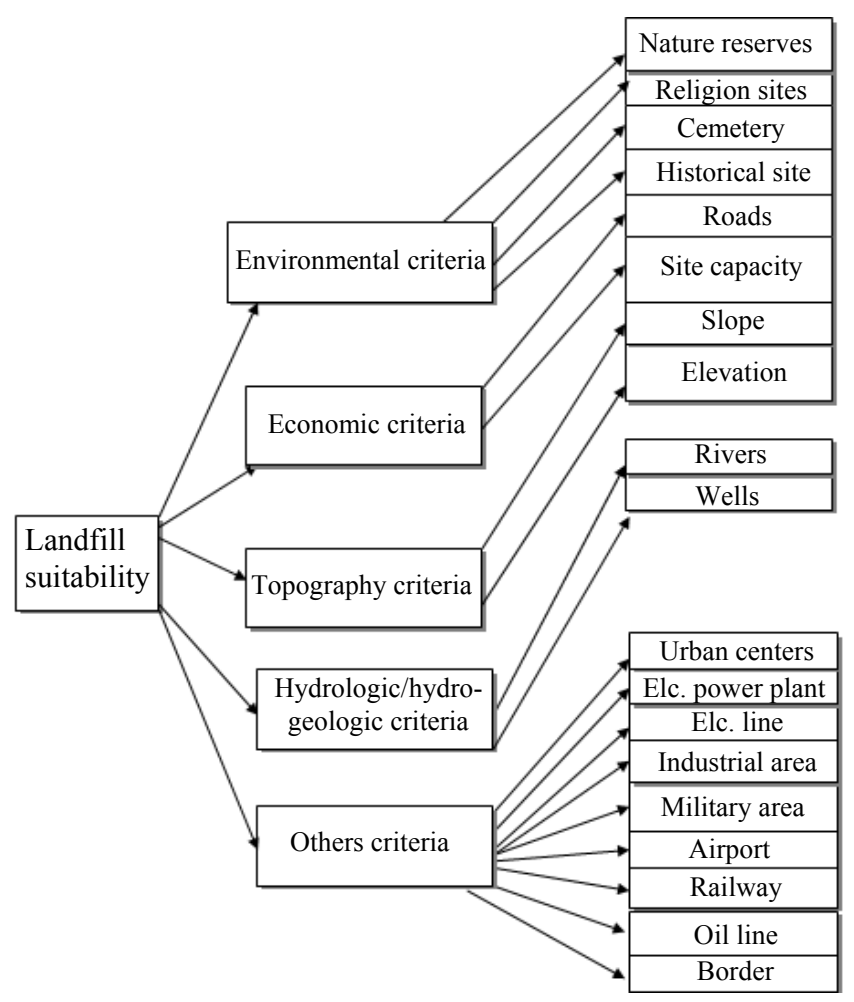

Fig. 4 Criteria decision tree developed for the landfill site selection problem in study area.

\begin{tabular}{|l|l|l|l|l|l|l|l|l|l|l|l|l|l|l|l|l|l|}
\hline & UC & CE & MR & HS & IS & NR & WE & OP & EP & SL & AP & PL & RO & RW & MS & BO & RS \\
\hline UC & 1 & 6 & 4 & 5 & 5 & 6 & 9 & 7 & 5 & 6 & 6 & 6 & 6 & 6 & 6 & 8 & 9 \\
\hline CE & $1 / 6$ & 1 & 1 & 1 & $1 / 2$ & 1 & 2 & 2 & 2 & 2 & 1 & 1 & 2 & 2 & 2 & 2 & 6 \\
\hline MR & $1 / 4$ & 1 & 1 & 5 & 3 & 4 & 7 & 5 & 5 & 3 & 5 & 5 & 6 & 7 & 4 & 5 & 6 \\
\hline HS & $1 / 5$ & 1 & $1 / 5$ & 1 & 2 & 2 & 3 & $1 / 2$ & 2 & 2 & 1 & 1 & $1 / 3$ & 2 & 1 & 3 & 2 \\
\hline IS & $1 / 5$ & 2 & $1 / 3$ & $1 / 2$ & 1 & 1 & 2 & 2 & 1 & 2 & 3 & $1 / 5$ & $1 / 2$ & 1 & $1 / 2$ & 1 & $1 / 2$ \\
\hline NR & $1 / 6$ & 1 & $1 / 4$ & $1 / 2$ & 1 & 1 & 2 & 1 & $1 / 2$ & 1 & $1 / 2$ & 1 & $1 / 2$ & $1 / 2$ & 1 & 1 & 1 \\
\hline WE & $1 / 9$ & $1 / 2$ & $1 / 7$ & $1 / 3$ & $1 / 2$ & $1 / 2$ & 1 & $1 / 2$ & $1 / 3$ & $1 / 4$ & $1 / 4$ & $1 / 2$ & $1 / 5$ & 1 & $1 / 4$ & $1 / 3$ & $1 / 2$ \\
\hline OP & $1 / 7$ & $1 / 2$ & $1 / 5$ & 2 & $1 / 2$ & 1 & 2 & 1 & 2 & 1 & 2 & 1 & 2 & 3 & $1 / 2$ & $1 / 2$ & $1 / 3$ \\
\hline EP & $1 / 5$ & $1 / 2$ & $1 / 5$ & $1 / 2$ & 1 & 2 & 3 & $1 / 2$ & 1 & 2 & 1 & 2 & 2 & 3 & 1 & 2 & 1 \\
\hline SL & $1 / 6$ & $1 / 2$ & $1 / 3$ & $1 / 2$ & $1 / 2$ & 1 & 4 & 1 & $1 / 2$ & 1 & 2 & 2 & 2 & 3 & $1 / 2$ & 3 & 2 \\
\hline AP & $1 / 6$ & 1 & $1 / 5$ & 1 & $1 / 3$ & 2 & 4 & $1 / 2$ & 1 & $1 / 2$ & 1 & 1 & 1 & 2 & 1 & 3 & 1 \\
\hline PL & $1 / 6$ & 1 & $1 / 5$ & 1 & 5 & 1 & 2 & 1 & $1 / 2$ & $1 / 2$ & 1 & 1 & $1 / 4$ & 2 & 1 & 2 & 2 \\
\hline RO & $1 / 6$ & $1 / 2$ & $1 / 6$ & 3 & 2 & 2 & 5 & $1 / 2$ & $1 / 2$ & $1 / 2$ & 1 & 4 & 1 & 5 & 3 & 4 & 3 \\
\hline RW & $1 / 6$ & $1 / 2$ & $1 / 7$ & $1 / 2$ & 1 & 2 & 1 & $1 / 3$ & $1 / 3$ & $1 / 3$ & $1 / 2$ & $1 / 2$ & $1 / 5$ & 1 & 2 & 2 & $1 / 2$ \\
\hline MS & $1 / 6$ & $1 / 2$ & $1 / 4$ & 1 & 2 & 1 & 4 & 2 & 1 & 2 & 1 & 1 & $1 / 3$ & $1 / 2$ & 1 & 2 & 2 \\
\hline BO & $1 / 8$ & $1 / 2$ & $1 / 5$ & $1 / 3$ & 1 & 1 & 3 & 2 & $1 / 2$ & $1 / 3$ & $1 / 3$ & $1 / 2$ & $1 / 4$ & $1 / 2$ & $1 / 2$ & 1 & 1 \\
\hline RS & $1 / 9$ & $1 / 6$ & $1 / 6$ & $1 / 2$ & 2 & 1 & 2 & 3 & 1 & $1 / 2$ & 1 & $1 / 2$ & $1 / 3$ & 2 & $1 / 2$ & 1 & 1 \\
\hline
\end{tabular}

Fig. 5 Comparison matrix.

*UC: urban centers; CE: cemetery; MR: main river; HS: historical site; IS: industrial site; NR: nature reserves; WE: wells; OP: oil pipes; EP: electrical power plant industrial areas; Sl: slope; AP: airports; PL: power lines; RO: roads; RW: railways; MS: military site BO: border; RS: religion site.

$\lambda_{\max }=19.525(\lambda$ : principal eigenvalue), $C I$ (consistency index) $=0.1578, R I$ (random index) $=1.71$ and $C R$ (consistency radio $)=0.09228<0.1$. 
Table 3 Scale for pairwise comparison [13].

\begin{tabular}{ll}
\hline $\begin{array}{l}\text { Intensity of } \\
\text { importance }\end{array}$ & Definition \\
\hline 1 & Equal importance \\
2 & Equal to moderately importance \\
3 & Moderate importance \\
4 & Moderate to strong importance \\
5 & Strong importance \\
6 & Strong to very strong importance \\
7 & Very strong importance \\
8 & Very to extremely strong importance \\
9 & Extreme importance \\
\hline
\end{tabular}

Table 4 Criteria final weights by AHP method.

\begin{tabular}{ll}
\hline Criteria & Final weight \\
\hline Urban centers & 0.233 \\
Main rivers & 0.148 \\
Roads & 0.067 \\
Historical sites & 0.050 \\
Electrical power lines & 0.044 \\
Oil pipes & 0.042 \\
Electrical power plant & 0.047 \\
Cemetery & 0.062 \\
Wells & 0.016 \\
Military sites & 0.044 \\
Regional sites & 0.033 \\
Slope & 0.046 \\
Airports & 0.041 \\
Industrial sites & 0.043 \\
Borders & 0.026 \\
Nature reserves & 0.031 \\
Railways & 0.028 \\
\hline
\end{tabular}

consideration. GIS is powerful tool designed for spatial analysis which provides functionality to capture, store, query, analyze, display and output geographic information.

The study of 17 input map layers is shown as follows:

(1) Settlement areas: In this study, settlement areas area was classified into two main types: first layer which consists of urban centre and second layer which consists of industrial areas. In the two types, different buffer zone distances to the urban centres and industrial areas were used. According to Ref. [15], the minimum distance from urban centres must be at least $5 \mathrm{~km}$ and $500 \mathrm{~m}$ from isolated houses to locate a landfill site. Table 5 shows the classes of industrial sites and Table 6 shows the classes of urban centers;

(2) Roads: A buffer of $500 \mathrm{~m}$ was taken for the roads network. Remaining areas were classified according to their suitability as in Table 7;

(3) Railways: There are many suggested distance as a buffer zones for railway [11, 16]. Suitable buffer zone of $500 \mathrm{~m}$ was taken for the railways (Table 8). The layer of railways was classified as suitable or unsuitable by assigning values 5 and 0 respectively as in Table 8;

(4) Slope: Land morphology is a principal factor in landfill construction process [17]. The slope layer was classified as suitable or unsuitable for a landfill site by assigning values 5 and 0 , respectively. Table 9 shows the classes for the slope;

(5) National borders: Because of the negative effects that may occur when undesirable facilities are

Table 5 Classes produced for the industrial areas of settlement criteria according to the suitability for landfill.

\begin{tabular}{ll}
\hline Distance to industrial area & Ranking \\
\hline $0 \sim 250 \mathrm{~m}$ & 0 \\
$>250 \mathrm{~m}$ & 5 \\
\hline
\end{tabular}

Table 6 Classes produced for the urban centers of settlement criteria according to the suitability for landfill.

\begin{tabular}{ll}
\hline Distance to urban centers & Ranking \\
\hline $0 \sim 5,000 \mathrm{~m}$ & 0 \\
$5,000 \sim 10,000 \mathrm{~m}$ & 5 \\
$10,000 \sim 15,000 \mathrm{~m}$ & 4 \\
$15,000 \sim 20,000 \mathrm{~m}$ & 2 \\
$>20,000 \mathrm{~m}$ & 1 \\
\hline
\end{tabular}

Table 7 Classes produced for the roads network criteria according to the suitability for landfill.

\begin{tabular}{ll}
\hline Distance to roads & Ranking \\
\hline $0 \sim 500 \mathrm{~m}$ & 0 \\
$500 \sim 1,000 \mathrm{~m}$ & 5 \\
$1,000 \sim 1,500 \mathrm{~m}$ & 4 \\
$1,500 \sim 2,000 \mathrm{~m}$ & 2 \\
$>2,000 \mathrm{~m}$ & 1 \\
\hline
\end{tabular}

Table 8 Classes produced for the railways according to the suitability for landfill.

\begin{tabular}{ll}
\hline Distance to railways & Ranking \\
\hline $0 \sim 500 \mathrm{~m}$ & 0 \\
$>500 \mathrm{~m}$ & 5 \\
\hline
\end{tabular}


Table 9 Classes produced for slope according to the suitability for landfill.

\begin{tabular}{ll}
\hline Classes for slope & Ranking \\
\hline$\leq 15 \%$ & 0 \\
$>15 \%$ & 5 \\
\hline
\end{tabular}

located near to a national borders or coastline, distance of 1 or $3 \mathrm{~km}$ were excluded respectively to guarantee an area's national development prospects (Table 10);

(6) Military area: These areas are used for the testing and storage of military equipment or training of military personnel and other military actions. Ref. [18] used 2,000 $\mathrm{m}$ as buffer zone for military area. In this study, 2,000 $\mathrm{m}$ was used as buffer zone as shown in Table 11;

(7) Oil pipes lines: Through the study area, the strategic crude oil pipeline is passing. So, there is a need for buffer zone for the pipeline on both sides. Refs. [11, 13] used $75 \mathrm{~m}$ as a buffer zone for both sides of oil pipe. Table 12 shows the buffer zone for this study;

(8) Power lines: Refs. [11, 13] suggested $30 \mathrm{~m}$ as a buffer zone on both sides of power line. This figure was adopted in this research (Table 13);

(9) Historical area: There are more than 100 historical sites in the study area. Ref. [16] used $500 \mathrm{~m}$ as buffer zone for all recreational areas, parks, cultural and historical landmarks region. According to nature of the study area as Islamic and culture centre, 1,500-m buffer zone was adopted as shown in Table 14;

(10) Airport: There is an airport located in the study area. It is called Al-Najaf Al-Ashref Airport. In this study, 3,000 $\mathrm{m}$ was considered as buffer zones as Ref. [13] used for the nearby Babylon City. The remaining area was classified according to their suitability as in Table 15;

(11) Main roads: The selected site should be away from main roads by a reasonable consideration to prevent the potential interference between solid waste transferring vehicles and the main traffic [17]. For this study, 500-m buffer was taken for the roads network.
Remaining area was classified according to their suitability as shown in Table 16;

(12) Surface water: Because of water pollution and water scarcity now in Iraq, it is certainly one of the most crucial issues. Surface water must be taken in mind and addressed correctly accordingly in landfill selection processes. Table 17 explains the main rivers classes used in this research;

(13) Sensitive sites (religious sites): Ref. [19] suggested $1,500 \mathrm{~m}$ for distance from sensitive buildings as religious sites and cemeteries and this figure

Table 10 Classes produced for national borders according to the suitability for landfill.

\begin{tabular}{ll}
\hline Distance to national borders & Ranking \\
\hline $0 \sim 100,000 \mathrm{~m}$ & 0 \\
$>100,000 \mathrm{~m}$ & 5 \\
\hline
\end{tabular}

Table 11 Classes produced for military area according to the suitability for landfill.

\begin{tabular}{ll}
\hline Distance to military area & Ranking \\
\hline $0 \sim 2,000 \mathrm{~m}$ & 0 \\
$>2,000 \mathrm{~m}$ & 5 \\
\hline
\end{tabular}

Table 12 Classes produced for oil pipe line according to the suitability for landfill.

\begin{tabular}{ll}
\hline Distance to oil lines & Ranking \\
\hline $0 \sim 75 \mathrm{~m}$ & 0 \\
$>75 \mathrm{~m}$ & 5 \\
\hline
\end{tabular}

Table 13 Classes produced for power line according to the suitability for landfill.

\begin{tabular}{ll}
\hline Distance to power lines & Ranking \\
\hline $0 \sim 30 \mathrm{~m}$ & 0 \\
$>30 \mathrm{~m}$ & 5 \\
\hline
\end{tabular}

Table 14 Classes produced for historical area according to the suitability for landfill.

\begin{tabular}{ll}
\hline Distance to historical area & Ranking \\
\hline $0 \sim 1,500 \mathrm{~m}$ & 0 \\
$>1,500 \mathrm{~m}$ & 5 \\
\hline
\end{tabular}

Table 15 Classes produced for airport according to the suitability for landfill.

\begin{tabular}{ll}
\hline Distance to airport & Ranking \\
\hline $0 \sim 3,000 \mathrm{~m}$ & 0 \\
$3,000 \sim 6,000 \mathrm{~m}$ & 1 \\
$6,000 \sim 9,000 \mathrm{~m}$ & 3 \\
$9,000 \sim 12,000 \mathrm{~m}$ & 4 \\
$>12,000 \mathrm{~m}$ & 5 \\
\hline
\end{tabular}


Table 16 Classes produced for the roads network criteria according to the suitability for landfill.

\begin{tabular}{ll}
\hline Distance to roads & Ranking \\
\hline $0 \sim 500 \mathrm{~m}$ & 0 \\
$500 \sim 1,000 \mathrm{~m}$ & 5 \\
$1,000 \sim 1,500 \mathrm{~m}$ & 4 \\
$1,500 \sim 2,000 \mathrm{~m}$ & 2 \\
$>2,000 \mathrm{~m}$ & 1 \\
\hline
\end{tabular}

Table 17 Classes produced for surface water according to the suitability for landfill.

\begin{tabular}{ll}
\hline Distance to main rivers & Ranking \\
\hline $0 \sim 250 \mathrm{~m}$ & 0 \\
$250 \sim 500 \mathrm{~m}$ & 1 \\
$500 \sim 750 \mathrm{~m}$ & 2 \\
$750 \sim 1,000 \mathrm{~m}$ & 4 \\
$>1,000 \mathrm{~m}$ & 5 \\
\hline
\end{tabular}

Table 18 Classes produced for the religious sites according to the suitability for landfill.

\begin{tabular}{ll}
\hline Distance to religious sites & Ranking \\
\hline $0 \sim 1,500 \mathrm{~m}$ & 0 \\
$>1,500 \mathrm{~m}$ & 5 \\
\hline
\end{tabular}

Table 19 Classes produced for the power plants according to the suitability for landfill.

\begin{tabular}{ll}
\hline Distance to power plant & Ranking \\
\hline $0 \sim 250 \mathrm{~m}$ & 0 \\
$>250 \mathrm{~m}$ & 5 \\
\hline
\end{tabular}

Table 20 Classes produced for the nature reserves according to the suitability for landfill.

\begin{tabular}{ll}
\hline Distance to nature reserves & Ranking \\
\hline $0 \sim 400 \mathrm{~m}$ & 0 \\
$>400 \mathrm{~m}$ & 5 \\
\hline
\end{tabular}

Table 21 Buffer zone distances and related rankings for cemetery in the study area.

\begin{tabular}{ll}
\hline Distance to cemetery & Ranking \\
\hline $0 \sim 1,500 \mathrm{~m}$ & 0 \\
$>1,500 \mathrm{~m}$ & 5 \\
\hline
\end{tabular}

Table 22 Classes produced for the wells according to the suitability for landfill.

\begin{tabular}{ll}
\hline Distance to wells & Ranking \\
\hline $0 \sim 400 \mathrm{~m}$ & 0 \\
$>400 \mathrm{~m}$ & 5 \\
\hline
\end{tabular}

was adopted in this research (Table 18);

(14) Infrastructure (electrical power plant): Infrastructure must be avoided from development and site selection process for landfill. Electrical power plant is considered as one of the most important infrastructure especially in Iraq. The suggested buffer zone for this purpose was $250 \mathrm{~m}$ (Table 19);

(15) Nature reserves: Some areas, assumed to be important natural flora and fauna and as a consequence they are unsuitable for as disposal site [20]. Table 20 shows the buffer zone distances and related rankings for the study area;

(16) Cemetery: Al-Najaf Governorate has been a top importance in a local, regional and international level due to its religious history and the presences of the very important mosque. Huge number of Muslims buries their dead in Al-Najaf cemetery from various countries. Therefore, excluding of cemetery area is one of most important criteria (Table 21);

(17) Wells: The potential waste disposal areas should be away from any water wells, otherwise, it can cause human and environmental irretrievable effects. All the locations of water wells in the study area were entered into GIS system and a buffer zone of $400 \mathrm{~m}$ around them was used (Table 22).

\section{Suitability Map}

In suitability modeling, the final step is to determine the relative importance of each data set, weight them accordingly and then combine the data sets to produce a suitability map. Weighting the data sets define the extent to which each data set will influence the model results. After preparation of all input data layers, one method was selected among the decision rules to analyze the data of the digital environment maps for landfill site selection using GIS. The selected method is SAW method. The output digital environmental maps produced by the method include the multiplication of data layers, weights and constraints. Suitability map showed that there are five landfill sites that can be selected after getting higher suitability index value (4.1 5) as shown in Fig. 6 .

The selected sites (five sites) have capacity more than required for damping solid waste that is expected 


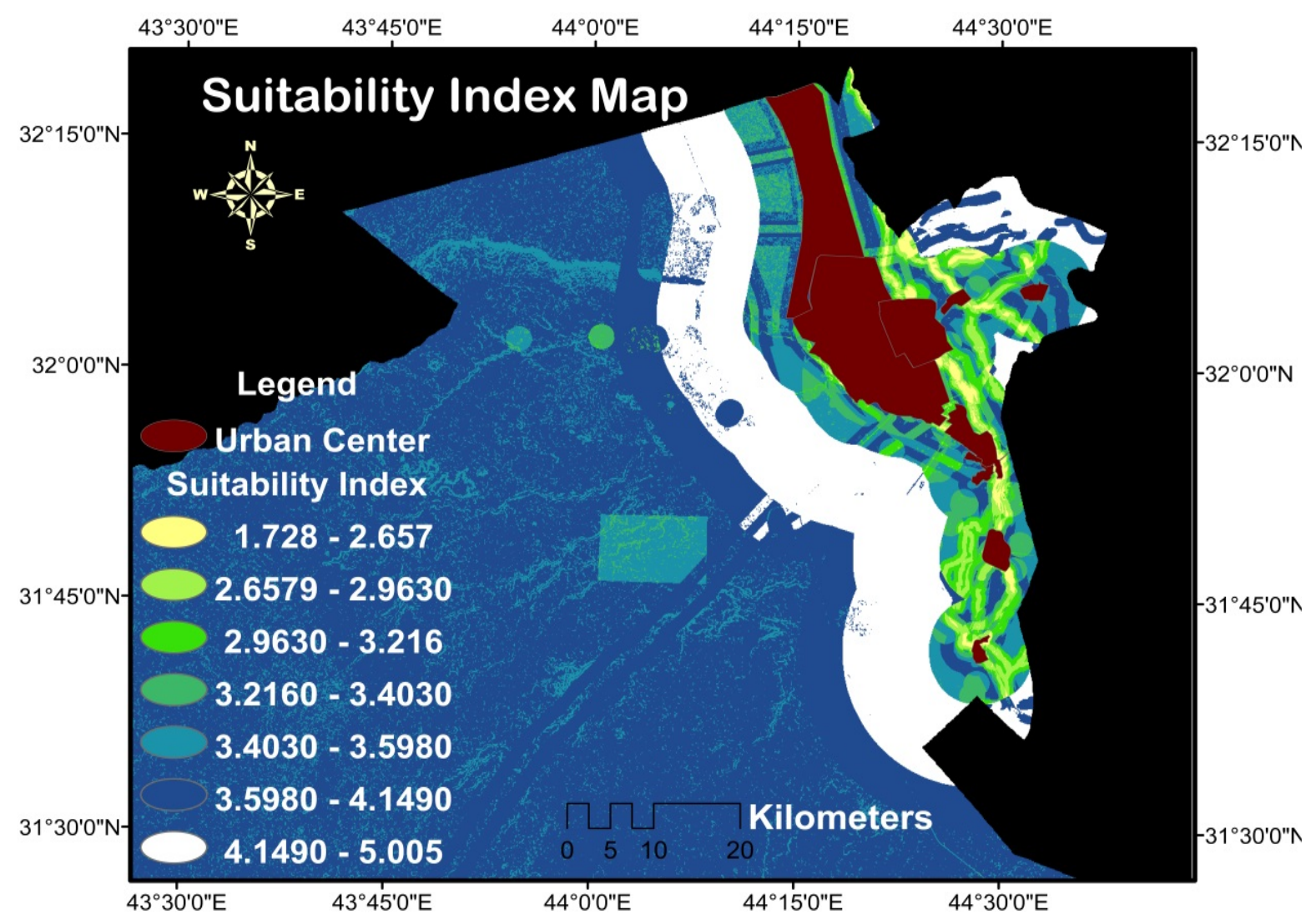

Fig. 6 Final suitability map.

Table 23 Selected landfill sites.

\begin{tabular}{lllll}
\hline Landfill name & Qadhaa serve & Coordinates & Available areas $\left(\mathrm{m}^{2}\right)$ & Suitability index \\
\hline Site 1 & Al-Manatheria Qadhaa & $\begin{array}{l}44^{\circ} 31^{\prime} 15^{\prime \prime} \mathrm{E} \\
31^{\circ} 37^{\prime} 51^{\prime \prime} \mathrm{N}\end{array}$ & $18,942,738$ & $>4.1$ \\
\hline Site 2 & Al-kufa Qadhaa & $\begin{array}{l}44^{\circ} 30^{\prime} 21^{\prime \prime} \mathrm{E} \\
32^{\circ} 01^{\prime} 08^{\prime \prime} \mathrm{N}\end{array}$ & $15,848,246$ & $>4.1$ \\
\hline Site 3 & Al-kufa Qadhaa & $\begin{array}{l}44^{\circ} 36^{\prime} 25^{\prime \prime} \mathrm{E} \\
32^{\circ} 03^{\prime} 40^{\prime \prime} \mathrm{N}\end{array}$ & $2,944,179$ & $>4.1$ \\
\hline Site 4 & Al-kufa Qadhaa & $\begin{array}{l}44^{\circ} 29^{\prime} 50^{\prime \prime} \mathrm{E} \\
32^{\circ} 10^{\prime} 09^{\prime \prime} \mathrm{N}\end{array}$ & $123,929,845$ & $>4.1$ \\
\hline Site 5 & Al- Najaf Qadhaa; & $\begin{array}{l}44^{\circ} 26^{\prime} 10^{\prime \prime} \mathrm{E} \sim 44^{\circ} 9^{\prime} 32^{\prime \prime} \mathrm{E} \\
31^{\circ} 51^{\prime} 50^{\prime \prime} \mathrm{N} \sim 31^{\circ} 54^{\prime} 36^{\prime \prime} \mathrm{N}\end{array}$ & $1,130,241,351$ & $>4.1$ \\
\hline
\end{tabular}

to be generated during 2015 2035 in Najaf Governorate (the required volume was 12,545,455 $\mathrm{m}^{3}$ and the available volume was $3,875,719,077 \mathrm{~m}^{3}$ ) (Table 23).

\section{Conclusions}

Najaf Governorate is located southwest Iraq with total area $28,824 \mathrm{~km}^{2}$ (6.6\% of Iraq) with a population that reaches $1,459,894$. Large number of religious tourists visits this city every year. The solid waste generated reached about $221,078 \mathrm{t}$ in 2016. There is no proper landfill site that fulfils the environmental requirements. In this research, GIS and MCDA were used based on 17 environmental, economic and geological criteria converted to input digital map layers to find the most suitable landfill sites to be used. The results of the analyses indicated that, urban centre, road network and main rivers criteria are the most important criteria for selection of the landfill site. Furthermore, the suitability map showed that there are 
five landfill sites that can be selected after getting higher suitability index value (4.1 5) as shown in Fig. 6. These sites have capacity more than required for damping solid waste that is expected to be generated during 2015 2035 in Najaf Governorate (the required volume was $12,545,455 \mathrm{~m}^{3}$ and the available volume was $3,875,719,077 \mathrm{~m}^{3}$ ). In addition, all of selected sites for landfilling in this study are located in a distance of $5 \mathrm{~km}$ from border of each qadhaa and that it is important from economic point of view.

\section{References}

[1] Reddy, P. J. 2011. Municipal Solid Waste Management. Boca Raton, Florida: Taylor \& Francis Group.

[2] Unnisa, S. A., and Rav, S. B. 2012. Sustainable Solid Waste Management. Boca Raton, Florida: Taylor \& Francis Group, Apple Academic Press, Inc.

[3] Chandrappa, R., and Das, D. B. 2012. Solid Waste Management Principles and Practice. Berlin: Springer-Verlag Berlin Heidelberg.

[4] The International Bank For Reconstruction and Development. 1999. Solid Waste Landfills in Middle- and Lower Income Countries A Technical Guide to Planning, Design, and Operation. World Bank technical paper No. 426.

[5] Akbari, V., Rajabi, M. A., Chavoshi, S. H., and Shams, R. 2008. "Landfill Site Selection by Combining GIS and Fuzzy Multi Criteria Decision Analysis, Case Study: Bandar Abbas, Iran.” World Applied Sciences Journal 3 (Supple 1): 39-47.

[6] Choudhury, C., and Das, S. 2012. "GIS and Remote Sensing for Landfill Site Selection-A Case Study on Dharmanagar Nagar Panchayet." IOSR (International Organization of Scientific Research) Journal of Environmental Science, Toxicology and Food Technology 1 (20): 36-43.

[7] Malczewski, J. 1997. "Propagation of Errors in Multicriteria Location Analysis: A Case Study." In Multiple Criteria Decision Making, edited by Fandel, G., and Gal, T. Berlin: Springer.

[8] Iraqi Ministry of Planning. 2015. Population Estimation Report. Najaf Estimation Directorate, Iraq.

[9] Hamoud, H. A. 2005. "Assessment and Development of Municipal Solid Waste Management in Najaf City.” M.Sc. thesis, University of Baghdad.

[10] Al-Baidhani, J. H., and Kadhum, R. H. 2009. "The Proposed Design of Bioreactor Landfill of Municipal Solid Waste Disposal in Hilla City." M.Sc. thesis, Babylon University.

[11] Şener, B. 2004. "Landfill Site Selection by Using Geographic Information Systems.” M.Sc. thesis, Middle East Technical University.

[12] Kontos, T. D., Komillis, D. P., and Halvadakis, C. P. 2003. "Siting MSW Landfills in Lesvos Island with a GIS Based Methodology." Waste Management and Research 21: 262-77.

[13] Jasim, H. K. 2012. "Using Environmental Information Database to Select Sanitary Landfills in Babylon Governorate." M.Sc. thesis, University of Babylon.

[14] Sumathi, V. R., Natesan, U., and Sarkar, C. 2008. "GIS-Based Approach for Optimized Siting of Municipal Solid Waste Landfill." Waste Management 28 (2008): 2146-60.

[15] Al-Anbari, R., Alnakeeb, A., and Abdulredha, M. A. 2013. "Landfill Site Selection for Kerbala Municipal Solid Wastes by Using Geographical Information System Techniques." Eng. \& Tech. Journal 32 (A): 13.

[16] Demesouka, O. E. ,Vavatsikos, A. P., and Anagnostopoulos, K. P. 2013. "Suitability Analysis for Siting MSW Landfills and Its Multicriteria Spatial Decision Support System: Method, Implementation and Case Study." Elsevier Ltd. Waste Management 33 (2013): 1190-206.

[17] Afzali, A., Samani, J. M. V., and Rashid, M. 2011. "Municipal Landfill Site Selection for Isfahan City by Use of Fuzzy Logic and Analytic Hierarchy Process." Iranian Journal of Environmental Health Science \& Engineering 8 (3): 273-84.

[18] Elalfy, Z., Elhadary, R., and Elashry, A. 2010. "Integrating GIS and MCDM to Deal with Landfill Site Selection." International Journal of Engineering \& Technology 10 (6): 33-40.

[19] Gisi, S. D., and Feo, G. D. 2010. "Using an Innovative Criteria Weighting Tool for Stakeholders Involvement to Rank MSW Facility Sites with the AHP." Waste Management 30 (2010): 2370-82.

[20] Ekmekçioglu, M., Kaya, T., and Kahraman, C. 2010. "Fuzzy Multicriteria Disposal Method and Site Selection for Municipal Solid Waste." Waste Management 30 (2010): 1729-36. 